
ISSN : 2615-1995, E-ISSN : 2615-0654

J. Madani., Vol. 3, No. 2, September 2020 (277 - 288)

(C)2018 Lembaga Kajian Demokrasi

dan Pemberdayaan Masyarakat (LKD-PM)

DOI : https://doi.org/10.33753/madani.v3i2.122

\title{
Analisis Pengaruh Komisaris Independen, Kepemilikan Institusional, dan Dept to Equity Ratio Terhadap Kinerja Keuangan
}

Sri Putri Winingrum W. A.

Fakultas Ekonomi, Universitas Pamulang

dosen02433@unpam.ac.id

\begin{abstract}
Abstrak
Tujuan dari penelitian ini adalah untuk mendapatkan bukti empiris mengenai hal-hal sebagai berikut: untuk menganalisis pengaruh komisaris independen terhadap kinerja keuangan, untuk menganalisis pengaruh kepemilikan institusional terhadap kinerja keuangan, untuk menganalisis pengaruh dept to equity ratio terhadap kinerja keuangan, dan untuk menganalisis pengaruh komisaris independen, kepemilikan institusional dan dept to equity ratio terhadap kinerja keuangan. Metode/Pendekatan berdasarkan pada judul dan permasalahan, maka jenis penelitian ini adalah penelitian asosiatif. Hasil Penelitian Hasil pengujian hipotesis pertama, Nilai Beta komisaris independen (komind) sebesar 0.615116 yang menandakan bahwa komisaris independen (komind) mempunyai pengaruh terhadap kinerja keuangan (knrkeu). Hasil pengujian hipotesis kedua, Nilai Beta kepemilikan institusional (kepinst) sebesar 0.007281 yang menandakan bahwa kepemilikan institusional (kepinst) mempunyai pengaruh terhadap kinerja keuangan (knrkeu). Hasil pengujian hipotesis ketiga, Nilai Beta dept to equity ratio (DER) sebesar -0.162996 yang menandakan bahwa dept to equity ratio (DER) mempunyai pengaruh terhadap kinerja keuangan (knrkeu). Hasil pengujian hipotesis keempat, Untuk uji signifikan regresi berganda dapat dilihat dari data dari hasil pengujian signifikan dan uji F. Kesimpulan hasil penelitian hasil pengujian hipotesis pertama, Nilai Beta komisaris independen (komind) menandakan bahwa komisaris independen (komind) mempunyai pengaruh terhadap kinerja keuangan (knrkeu). Hasil pengujian hipotesis kedua, Nilai Beta kepemilikan institusional (kepinst) menandakan bahwa kepemilikan institusional (kepinst) mempunyai pengaruh terhadap kinerja keuangan (knrkeu). Hasil pengujian hipotesis ketiga, Nilai Beta dept to equity ratio (DER) menandakan bahwa dept to equity ratio (DER) mempunyai pengaruh terhadap kinerja keuangan (knrkeu). Hasil pengujian hipotesis keempat, Untuk uji signifikan regresi berganda dapat dilihat dari data dari hasil pengujian signifikan dan uji $F$.
\end{abstract}

Kata Kunci : Kinerja Keuangan, Komisaris Independen, Kepemilikan Institusional, DER

\begin{abstract}
The purpose of this study is to obtain empirical evidence about the influence of independent commissioners on financial performance, analyze the effect of institutional ownership on financial performance, analyze the effect of DER on financial performance, and to analyze the influence of independent commissioners, institutional ownership and DER on financial performance. The method / approach of this research is associative research. The results of the first hypothesis research, the Independent Commissioner Beta value of 0.615116 indicates that the independent commissioner has an influence on financial performance. The second hypothesis testing results, Beta value of institutional ownership of 0.007281 indicates institutional ownership has an influence on financial performance. The results of testing the third hypothesis, the DER Beta Value of -0.162996 indicates that the DER has an influence on financial performance. The fourth hypothesis testing results, the significance test of multiple regression seen from the data from the results of significant testing and $F$ test. Conclusion of
\end{abstract}


the results of the first hypothesis testing, the Beta value of the independent commissioner indicates that the independent commissioner has an influence on financial performance. The results of the second hypothesis testing, Beta value of institutional ownership indicates institutional ownership has an influence on financial performance. The third hypothesis testing results, Beta value dept to equity ratio indicates the DER has an influence on financial performance. The fourth hypothesis testing results, a significant test of multiple regression can be seen from the data of the significant test results and the F test.

Keywords : Financial Performance, Independent Board, Institutional Ownership, DER

\section{PENDAHULUAN}

Salah satu sektor industri yaitu Food and Beverage merupakan salah satu jenis sektor usaha yang terus mengalami pertumbuhan dan perkembangan. Sejalan dengan meningkatnya pertumbuhan jumlah penduduk di Indonesia, jumlah kebutuhan terhadap Food and Beverage pun terus meningkat. Kecenderungan masyarakat Indonesia untuk menikmati makanan siap saji menyebabkan banyak bermunculan perusahaanperusahaan baru dibidang makanan dan minuman. Oleh karena itu persaingan antar perusahaan pun semakin kuat dan semakin ketat. Dengan persaingan yang semakin ketat ini menuntut perusahaan untuk dapat memperkuat fundamental agar perusahaan-perusahaan mereka dapat bersaing dengan perusahaan global. Jika fundamental tersebut kurang kuat akan mengakibatkan penurunan volume perusahaan sehingga perusahaan akan mengalami kebangkrutan dan kerugian.

Disisi lain perkembangan usaha saat ini sangat menuntut para pelaku usaha untuk lebih tanggap terhadap setiap perubahan yang ada pada dunia bisnis saat ini. Dalam menjalankan kegiatan usahanya perusahaan tidak hanya dituntut harus untuk meningkatkan kesejahteraan pemegang saham saja, namun juga mampu mengakomodasi bagi pihak-pihak yang berkepentingan lainnya. Dan perusahaan juga harus mampu memenuhi tuntutan masyarakat yang semakin beragam atas kebutuhannya. Terlebih dengan kondisi perekonomian di Negara Indonesia yang selalu dilanda goncangan memaksa perusahaan harus mampu beradaptasi dengan kondisi seperti ini dengan cara meningkatkan nilai tambah perusahaan agar mampu bersaing.

Disisi lain tujuan utama perusahaan ada- lah memaksimalkan nilai perusahaan atau meningkatkan tingkat kemakmuran para pemegang saham. Tingkat kesehatan perusahaan penting artinya bagi perusahaan untuk meningkatkan efisiensi dalam menjalankan kegiatan usahanya, sehingga kemampuan untuk memperoleh keuntungan dapat ditingkatkan dan untuk menghindari adanya potensi kebangkrutan atau kerugian.

Dalam dunia usaha seorang manager harus bisa mengetahui apakah perusahaan yang dia pimpindalamkeadaan sehatatautidak, perusahaan yang tidak sehat akan cepat mengalami kegagalan, akibatnya kebangkrutanpun melanda perusahaan tersebut. Atau dapat dikatakan perusahaan gagal menjalankan usahanya untuk mendapatkan laba guna kebutuhan perusahaan dan masyarakat.

Indonesia memasuki kondisi perdagangan bebas, yang di maksud dengan perdagangan bebas adalah pemerintah tidak melakukan pembedaan antara kegiatan ekspor dan kegiatan impor. Dalam kegiatan perdagangan tersebut terdapat investor baik dari dalam negeri maupun dari luar negeri. Para investor dalam melakukan penanaman modal terhadap perusahaan akan melihat beberapa faktor antara lain laporan keuangan dan kinerja perusahaan tersebut.

Terkait dengan penilaian kinerja suatu perusahaan, laporan keuangan perusahaan tersebut sering kali dijadikan dasar atau tolak ukur penilaian keberhasilan perusahaan. Laporan keuangan utama di dalam akuntansi terdapat lima jenis diantaranya laporan neraca, laporan laba rugi, laporan perubahan modal, laporan arus kas, dan catatan atas laporan keuangan. Investor seringkali melihat laporan laba rugi sebagai dasar penilaian, tetapi di satu sisi laporan laba rugi kurang dapat mencerminkan keadaan laba 
rugi sebenarnya dalam perusahaan khususnya dalam hal laba. Hal tersebut disebabkan karena adanya beberapa metode pengakuan laba dalam perusahaan. Selain laporan laba rugi investor juga dapat melihat laporan arus kas perusahaan, adapun laporan arus kas atau yang biasa di sebut Cash Flow dalam perusahaan memuat seluruh aliran kas perusahaan seperti pemasukan dan pengeluaran.

Yang di maksud dengan kinerja keuangan dalam perusahaan yaitu gambaran mengenai keadaan keuangan perusahaan dalam jangka waktu tertentu yang merupakan hasil dari banyak keputusan individual yang dibuat secara terus menerus oleh manajemen. Oleh karena itu untuk menilai kinerja keuangan suatu perusahaan, perlu dianalisa dampak keuangan kumulatif dan ekonomi dari keputusan dan mempertimbangkannya dengan menggunakan ukuran komparatif (Sucipto, 2013).

Cash Flow Return on Assets dapat dihitung melalui perhitungan laba sebelum bunga dan pajak ditambah depresiasi dibagi dengan total aktiva (Muhammad dan Bambang, 2007 dalam Adi, 2009). CFROA merupakan salah satu pengukuran kinerja perusahaan yang menunjukkan kemampuan aktiva perusahaan untuk menghasilkan laba operasi CFROA lebih memfokuskan pada pengukuran kinerja perusahaan saat ini dan CFROA tidak terikat dengan harga saham (Cornett et al., 2006 dalam Ujiyantho, 2007).

Dalam beberapa hal terkait dengan kinerja keuangan, kinerja keuangan sendiri seringkali dijadikan dasar dalam menentukan tingkat laba. Perusahaan merencanakan laba untuk dijadikan dasar penerapan sesuai dengan strategi yang diterapkan perusahaan. Seorang manajer perusahaan akan selalu berusaha meningkatkan laba jangka pendek agar penilaian kinerjanya bernilai positif. Tetapi penilaian jangka pendek tersebut belum tentu berdampak baik pada penilaian jangka panjang dari kinerja keuangan perusahaan tersebut.

Seorang investor akan memikirkan keuntungan dan kerugian ketika akan menanamkan modalnya di dalam suatu perusahaan. Kiner- ja keuangan yang dianggap tidak baik kedepannya akan memberikan kesan bahwa perusahaan tersebut belum tentu dapat memberikan keuntungan atau paling tidak dapat mengembalikan modal sesuai dengan investasi yang telah disetorkan.

Metode penilaian kinerja keuangan perusahaan berorientasi pada data keuangan yang dipublikasikan dan dibuat sesuai dengan Prinsip Akuntansi Keuangan yang berlaku umum dan diterima umum. Laporan keuangan merupakan data yang paling sering digunakan dan yang tersedia untuk penilaian kinerja keuangan perusahaan, walaupun banyak yang beranggapan bahwa kinerja keuangan dapat mewakili hasil dan kondisi ekonomi perusahaan.

Penerapan dan pengelolaan corporate governance yang baik merupakan sebuah konsep yang mengungkapkan (disclosure) semua informasi kinerja keuangan perusahaan secara akurat, tepat waktu dan transparan. Oleh sebab itu, baik perusahaan publik maupun non publik diwajibkan memandang corporate governance bukan sebagai aksesoris belaka, tetapi sebagai upaya peningkatan kinerja serta nilai perusahaan (Tjager, 2003 dalam Darmawati 2004).

Corporate governance membantu terciptanya hubungan yang tertata serta terjaga dan dapat dipertanggungjawabkan di antara unsur-unsur dalam perusahaan (Dewan Komisaris, Dewan Direksi, dan para pemegang saham) dalam upaya meningkatkan kinerja perusahaan tersebut. Dalam pandangan seperti ini, dewan komisaris berada pada posisi untuk memastikan dan menilai bahwa manajemen sudah benar-benar bekerja demi kepentingan perusahaan sesuai dengan strategi yang telah ditetapkan dan diharapkan juga dapat menjaga kepentingan para pemegang saham, diantaranya untuk meningkatkan nilai ekonomis perusahaan tersebut. Demikian juga dewan komite audit mempunyai peran yang sangat penting dan strategis dalam hal memelihara kredibilitas dan objektivitas dalam proses penyusunan laporan keuangan seperti halnya menjaga terciptanya sistem pengawasan perusahaan yang memadai dan dapat dipertanggungjawabkan serta dilaksanakannya Corporate Governance, (Im- 
proving Audit Committee Performance: What Works Best-A Research Report prepared by Pricewaterhouse Coopers, the Institute of Internal Auditors Research Foundation).

Negara Indonesia sendiri, memuat mengenai isu corporate governance yang mengemuka setelah terjadinya krisis ekonomi yang memakan waktu yang cukup lama sejak tahun 1998 dan saat terjadinya beberapa kasus serupa di dunia bisnis, misalnya saja seperti kasus PT. Kimia Farma dan PT. Bank Lippo. Pada Bank Lippo terjadi kasus pemalsuan angka dalam laporan keuangan perusahaan berganda yang dilakukan oleh staff dari perusahaan itu sendiri. Laporan keuangan pada PT Bank Lippo yang telah dimanipulasi dalam hal pemalsuan angka dan menyalahgunakan transaksi jual beli saham dipasar modal menimbulkan terjadinya turunnya harga saham pada awal tahun 2003 sehingga PT. Bank Lippo memperoleh hak untuk melakukan rencana right issue (penerbitan saham baru pada pasar modal). Sedangkan pada PT. Kimia Farma seorang direksi terbukti melakukan pelanggaran dengan menggelembungkan laba bersih dilaporan keuangan perusahaan milik negara (BUMN sebagai pemegang saham mayoritas) untuk tahun buku 2001. Penggelembungan tersebut bertujuan agar investor menilai baik kinerja perusahaan tersebut. Kasus tersebut terjadi karena beberapa faktor diantaranya kurangnya pengawasan dari dalam perusahaan tersebut baik komisaris independen maupun pihak luar perusahaan yaitu kepemilikan institusional. Hadirnya corporate governance memberikan syarat suatu pengelolaan yang baik dalam sebuah organisasi. Menurut Wardhani (2006) lemahnya penerapan corporate governance pada perusahannya memberikan dampak pada lamanya proses perbaikan krisis yang terjadi di Indonesia saat ini. Oleh karena itu, pihak pemerintah dan investor mulai memberikan perhatian yang lebih terhadap praktek corporate governance dalam perusahaan.

Menurut Organization for Economic and Development (OECD) (Transfer Pricing Guidelines for Multinational Enterprises and Tax Administration, July 2016), corporate governance adalah suatu struktur untuk menempatkan tujuan dari perusahaan, sarana atau media untuk mencapai tujuan tersebut adalah menentukan pengawasan atas kinerja perusahaan. Menurut Bodroastuti (2009) mekanisme corporate governance dapat menciptakan nilai tambah bagi semua pihak-pihak yang berkepentingan, sehingga konflik antara pihak agen dan principal yang berdampak pada agency cost dapat terhindarkan.

Penerapan corporate governance yang baik, manajer perusahaan akan selalu mengambil tindakan yang tepat dan tidak mementingkan kepentingan diri sendiri, serta dapat melindungi stakeholders perusahaan. Menerapkan mekanisme corporate governance yang baik dan terstruktur serta tertata akan menekan risiko perusahaan mengalami financial distress atau kesulitan keuangan. Dengan adanya ancaman tersebut menyebabkan para manajer berpikir kembali mengenai strategi-strategi yang layak untuk mengantisipasi kondisi-kondisi yang menyebabkan terjadinya permasalahan-permasalahan keuangan tersebut.

Tidak sedikit pengambilan keputusan yang salah, dan kelemahan-kelemahan yang saling berhubungan yang dapat memberikan dampak secara langsung maupun tidak langsung kepada manajemen serta tidak terdapatnya atau kurangnya upaya mengawasi dan mengendalikan kondisi keuangan sehingga penggunaan keuangan tidak sesuai dengan kebutuhan dapat memicu terjadinya kesulitan keuangan.

Corporate governance disadari cukup mampu menjelaskan perbedaan kinerja antar negara selama periode krisis serta perbedaan kinerja antar perusahaan-perusahaan dalam suatu negara tertentu. Oleh karena itu, corporate governance dapat dijadikan salah satu faktor yang berpengaruh signifikan saat terjadinya kondisi krisis. Perusahaan dengan penerapan corporate governance akan mengalami perbaikan dalam hal perbaikan citra dan peningkatan nilai perusahaan. Disisi lain penelitian tentang variasi penerapan corporate governance di tingkat perusahaan masih sangat sedikit dilakukan.

Dengan terukurnya praktik corporate governance pada tingkatan perusahaan, banyak penelitian yang menemukan adanya hubungan positif 
baik dalam corporate governance dengan nilai atau kinerja perusahaan (Arief,dkk 2015).

Menurut Kakabadse dkk, (2001) dalam Darmawati, (2004) hasil yang berbeda penelitian corporategovernance dengannilaikinerjakeuangan disebabkan oleh beberapa hal yang terjadi, yaitu: suatu perspektif teoritis yang diterapkan, metodologi penelitian, pengukuran kinerja, dan perbedaan pandangan atas keterlibatan dewan dalam pengambilan keputusan.

Meskipun penelitian-penelitian tentang hubungan corporate governance dengan kinerja perusahaan menunjukkan hasil yang berbeda, namun keseluruhan menyatakan bahwa corporate governance mempunyai pengaruh atau berdampak terhadap kinerja perusahaan.

Dewan komisaris yang independen secara pengawasan lebih baik terhadap manajemen perusahaan, sehingga mengurangi kemungkinan kecurangan dalam penyajian (Chtourou, et al. 2001 dalam Arief \& Bambang, 2007). Seorang Komisaris independen di dalam satu perusahaan harus benar-benar independen dan dapat menolak pengaruh, intervensi maupun tekanan dari pemegang saham terutama yang memiliki kepentingan umum atas transaksi atau kepentingan tertentu perusahaan (Weisbach, 1988 dalam Arifin, 2005). Dengan adanya komisaris independen diduga dan diharapkan dapat berpengaruh terhadap ketepatan waktu pelaporan keuangan.

Kepemilikan institusional yaitu kepemilikan saham perusahaan yang dimiliki oleh institusi baik lembaga seperti perusahaan asuransi, bank dan perusahaan investasi lainnya (Tarjo, 2008). Kepemilikan institusional memiliki peranan penting dalam memonitor manajemen karena dengan adanya kepemilikan oleh institusional akan mendorong pengawasan yang lebih optimal di dalam perusahaan. Monitoring tersebut tentunya akan menjamin kemakmuran untuk pemegang saham, pengaruh kepemilikan institusional sebagai agen pengawas ditekan melalui investasi mereka yang cukup besar dan berpengaruh dalam pasar modal.

Kepemilikan institusional, dimana umumnya dapat bertindak sebagai pihak yang memo- nitor atau mengawasi perusahaan. Semakin besar kepemilikan institusional maka semakin efektif dan efisien pemanfaatan aktiva perusahaan dan diharapkan dapat bertindak sebagai pencegahan terhadap pemborosan yang dilakukan oleh menajemen perusahaan (Faizal, 2004). Kepemilikan institusional oleh peneliti dipercaya dapat mempengaruhi kinerja di dalam suatu perusahaan. Institusi dengan investasi yang substansial pada saham perusahaan memperoleh insentif yang lebih besar secara aktif memonitor dan mempengaruhi tindakan manajemen perusahaan.

Pada dasarnya pengelola modal kerja yang efektif dan efisien akan sangat mempengaruhi posisi keuangan perusahaan terutama akan meningkatkan kinerja keuangan perusahaan itu sendiri. Pengelolaan kebutuhan modal kerja mempunyai hubungan yang sangat erat dan sangat berkaitan dengan kegiatan rutin dari perusahaan, maka diharapkan dari perusahaan dapat memperhitungkan kebutuhan dan sumber pemenuhan modal kerja yang tepat bagi perusahaan untuk meningkatkan kinerja keuangan perusahaan tersebut.

Menurut Kasmir (2008:151) tingkat rasio solvabilitas atau leverage merupakan rasio yang digunakan untuk mengukur dan menghitung sejauh mana aktiva perusahaan di biaya dengan hutang. Hal tersebut memiliki arti berapa besar beban utang yang ditanggung perusahaan dibandingkan dengan aktivanya. Dalam arti luas dikatakan bahwa rasio solvabilitas digunakan untuk mengukur kemampuan perusahaan untuk membayar seluruh kewajibannya, baik jangka pendek maupun jangka panjang apabila perusahaan dibubarkan (di likuidasi).

Biasanya penggunaan tingkat rasio solvabilitas atau leverage disesuaikan dengan tujuan dari perusahaan itu sendiri. Artinya perusahaan dapat menggunakan rasio leverage secara keseluruhan atau sebagian dari masing-masing jenis tiap-tiap rasio solvabilitas yang ada. Penggunaan rasio secara keseluruhan, artinya seluruh jenis rasio yang dimiliki perusahaan, sedangkan sebagian artinya perusahaan hanya menggunakan beberapa jenis rasio yang dianggap perlu untuk diketahui oleh perusahaan. 
Adapun jenis-jenis rasio yang ada dalam rasio solvabilitas dalam perusahaan antara lain : Debt to Asset Ratio, Debt to Equity Ratio, Long Term Debt to Equity Ratio, Times Interest Earned Ratio, Long Term Debt to Non Current Asset, Tangible Assets Debt Coverage (TADC), Current Liabilities to Net Worth.

Dalam penelitian ini peneliti mengambil satu unsur dari leverage yaitu Debt to Equity Ratio (DER) merupakan rasio yang digunakan untuk menilai tingkat hutang dengan nilai ekuitas. Rasio ini dicari dengan cara membandingkan antara seluruh hutang, termasuk hutang lancar dengan seluruh ekuitas dalam perusahaan.

Penelitian ini mencoba menguji pengaruh komisaris independen, kepemilikan institusional dan dept to equity ratio terhadap kinerja keuangan. Namun, penelitian sebelumnya belum terlalu banyak yang menggunakan salah satu variabel leverage yaitu dept to equity ratio maka penulis menambahkan variabel dept to equity ratio. Sampel yang digunakan dalam kegiatan penelitian ini adalah perusahaan food and beverage yang terdaftar di Bursa Efek Indonesia periode 2012-2016.

\section{METODE}

Didasarkan dari judul dan permasalahan yang ada, maka jenis penelitian ini adalah penelitian asosiatif. Pengertian dari Penelitian asosiatif adalah penelitian yang bertujuan untuk menganalisis bagaimana suatu variabel mempengaruhi variabel lain. Jenis data yang dipakai dalam melakukan penelitian ini adalah data dokumenter. Dan sumber data dalam penelitian ini adalah data sekunder yang memiliki arti data seluruh perusahaan food and beverage yang terdaftar di BEI tahun 2012-2016. Populasi dalam penelitian ini adalah jenis perusahaan food and beverage yang terdaftar di Bursa Efek Indonesia pada tahun 2012-2016. Kriteria pengambilan sampel dengan metode purposive sampling, yaitu pemilihan sampel yang didasarkan atas kriteriakriteria tertentu.

Kriteria sampel meliputi hal-hal sebagai berikut : (a) Perusahaan food and beverage yang terdaftar di Bursa Efek Indonesia periode tahun
2012-2016; (b) Perusahaan food and beverage yang tidak keluar kepesertaanya di BEI selama pengamatan tahun 2012-2016; (c) Perusahaan food and beverage yang menerbitkan serta menyajikan laporan keuangan dalam mata uang rupiah; (d) Perusahaan food and beverage yang menerbitkan dan menyajikan laporan keuangan lengkap sesuai data yang diperlukan dalam penelitian; (e) Perusahaan food and beverage yang tidak melakukan akuisisi dan merger (yaitu perusahaan yang tidak melakukan pengambilalihan saham perseroan lain atau menggabungkan diri dengan perseroan lain) dan tidak mengalami perubahan sektor industri maupun perubahan nama selama periode 2012-2016 sesuai dengan data yang peneliti butuhkan. Dari kriteria tersebut terdapat 13 perusahaan food and beverage yang dijadikan sebagai sampel.

Terdapat dua jenis variabel yang digunakan didalam melakukan penelitian ini. Variabel-variabel tersebut yaitu terdiri dari variabel dependen dan variabel independen. Variabel dependen $(\mathrm{Y})$ yang dimaksud dalam penelitian ini adalah kinerja keuangan. Sedangkan yang termasuk variabel independennya $(\mathrm{X})$ adalah dewan komisaris $\left(\mathrm{X}_{1}\right)$, kepemilikan institusional $\left(\mathrm{X}_{2}\right)$, dan dept to equity ratio $\left(\mathrm{X}_{3}\right)$.

Variabel tingkat porsi dewan komisaris independen $\left(\mathrm{X}_{1}\right)$ dapat diukur dengan menggunakan indikator presentase anggota dewan komisaris yang berasal dari luar perusahaan dari seluruh ukuran anggota dewan komisaris yang terdapat didalam perusahaan tersebut. Kepemilikan institusional $\left(\mathrm{X}_{2}\right)$ dalam penelitian ini dapat dihitung dengan cara membagi jumlah pihak institusi dan blackholder dengan saham yang beredar. Dept to equity ratio $\left(\mathrm{X}_{3}\right)$ dalam penelitian ini dapat pula dihitung dengan cara membagi total hutang dengan modal yang terdapat dalam perusahaan.

Kinerja keuangan $(\mathrm{Y})$ memberikan arti kinerja fundamental perusahaan dan diukur dengan data yang berasal dari laporan keuangan perusahaan. Kinerja keuangan dalam penelitian ini diukur dengan menggunakan Cash Flow Return On Assets (CFROA). CFROA dihitung dengan rasio dari laba sebelum bunga dan pajak ditambah depresiasi dibagi dengan total aktiva (Arief dan 
Bambang, 2007:12).

Dalam kesempatan penelitian saat ini, teknik yang diterapkan adalah teknik analisis berganda, karena terdapat variabel bebas dalam penelitian ini lebih dari satu variabel. Teknik analisis berganda merupakan teknik uji yang digunakan untuk mengetahui sejauh mana pengaruh tingkat dari variabel independen terhadap variabel dependen. Persamaan analsisi regresi bergada dapat dirumuskan sebagai berikut:

$\begin{array}{ll}\mathrm{Y} & =\mathrm{a}+\mathrm{b}_{1} \mathrm{X}_{1}+\mathrm{b}_{2} \mathrm{X}_{2}+\mathrm{b}_{3} \mathrm{X}_{3}+\mathrm{e} \\ \text { Dimana : } & \\ \mathrm{Y} & : \text { Kinerja keuangan } \\ \mathrm{a} & : \text { Konstanta } \\ \mathrm{b}_{1}, \mathrm{~b}_{2}, \mathrm{~b}_{3}: & \text { Koefisien regresi variabel inde- } \\ & \text { penden } \\ \mathrm{X}_{1} & : \text { Dewan komisaris } \\ \mathrm{X}_{2} & : \text { Kepemilikan Institusional } \\ \mathrm{X}_{3} & : \text { Dept to equity ratio } \\ \mathrm{e} & : \text { Error }\end{array}$

\section{HASIL dan PEMBAHASAN}

\section{Hasil}

\section{Pengujian Hipotesis}

\section{Uji Koefisien Determinasi $\left(R^{2}\right)$}

Koefisien determinasi $\left(\mathrm{R}^{2}\right)$ memberikan penjelasan proporsi variabel terkait jadi dapat dijelaskan oleh variabel bebas secara bersamaan. Nilai koefisien determinasi berkisaran anatar $0<\mathrm{R}^{2}<1$. Bila nilai $\mathrm{R}^{2}$ semakin mendekati satu maka vaiabel bebas yang ada semakin besar dalam menjelaskan variabel terikat, tetapi disisi lain bila nilai $\mathrm{R}^{2}$ mendekati 0 maka variabel bebas semakin kecil dalam menjelaskan variabel terikat.

Hasil pengujian hipotesis diperoleh nilai adjusted $\mathrm{R}^{2}$ sebesar 0,282341 sehingga dapat disimpulkan bahwa variabel indepnden bisa menjelaskan sebesar 28,2341\% terhadap variabel dependen, sedangkan sisanya sebesar 71,7659\% dijelaskan oleh faktor lain diluar model persamaan regresi tersebut.

\section{Hasil Uji Pengaruh Simultan (F test)}

Uji pengaruh simultan (uji F) dilakukan bertujuan untuk mengetahui nilai apakah variabel independen secara bersama-sama atau simultan mempengaruhi variabel dependen. Untuk uji signifikan regresi berganda dapat dilihat dari data hasil pengujian signifikan dan uji F. Hasilnya dapat dilihat pada tabel bahwa nilai $\mathrm{F}_{\mathrm{o}}=9.392946$ dengan nilai signifikan sebesar $0.000034<0.05$ yang berarti komisaris independen (komind), kepemilikan institusional (kepinst) dan dept to equity ratio (DER) secara bersama-sama mempunyai pengaruh terhadap kinerja keuangan (knrkeu).

\section{Uji Signifikansi Parameter Regresi}

Keandalan model regresi yang digunakan sebagai alat estimasi sangat ditentukan oleh signifikansi parameter-parameter dalam model yaitu koefisien regresi. Uji signifikansi dilakukan dengan statistik t (uji t). Uji t dilakukan untuk menguji signifikansi koefisien regresi secara parsial dari variabel independennya (Ghozali, 2005).

Dari hasil perhitungan tersebut dapat disimpulkan bahwa variabel kinerja keuangan (CFROA) dipengaruhi oleh komisaris independen, kepemilikan institusional dan dept to equity ratio dengan hasil sebagai berikut: Untuk uji signifikan regresi parsial dapat dilihat dari hasil pengujian signifikan dengan uji t. Beta komisaris independen (komind) sebesar 0.615116 yang menandakan bahwa komisaris independen (komind) mempunyai pengaruh terhadap kinerja keuangan (knrkeu). Nilai signifikan sebesar $0.0888>0.05$ dengan nilai $t_{\text {hitung }}$ sebesar 1.729167 $<\mathrm{t}_{\text {tabel }}$ sebesar 1.9990 yang berarti komisaris independen (komind) tidak berpengaruh terhadap kinerja keuangan (knrkeu) secara parsial. Untuk uji signifikan regresi parsial dapat dilihat dari hasil pengujian signifikan dengan uji t. Beta kepemilikan institusional (kepinst) sebesar 0.007281 yang menandakan bahwa kepemilikan institusional (kepinst) mempunyai pengaruh terhadap kinerja keuangan (knrkeu). Nilai signifikan sebesar $0.3332>0.05$ dengan nilai $\mathrm{t}_{\text {hitung }}$ sebesar $0.975368<\mathrm{t}_{\text {tabel }}$ sebesar 1.9990 yang berarti kepemilikan institusional (kepinst) tidak berpengaruh terhadap kinerja keuangan (knrkeu) secara parsial. Untuk uji signifikan regresi parsial dapat dilihat dari hasil pengujian signifikan dengan uji t. Beta dept to equity ratio 
(DER) sebesar -0.162996 yang menandakan bahwa dept to equity ratio (DER) mempunyai pengaruh terhadap kinerja keuangan (knrkeu). Nilai signifikan sebesar $0.0000>0.05$ dengan nilai $\mathrm{t}_{\text {hitung }}$ sebesar $-5.051495<\mathrm{t}_{\text {tabel }}$ sebesar 1.9990 yang berarti dept to equity ratio (DER) mempunyai pengaruh terhadap kinerja keuangan (knrkeu) secara parsial.

\section{Pembahasan}

Hasil pengujian dari hipotesis pertama, Nilai Beta komisaris independen (komind) sebesar 0.615116 yang menandakan bahwa komisaris independen (komind) mempunyai pengaruh terhadap kinerja keuangan (knrkeu). Nilai signifikan sebesar $0.0888>0.05$ dengan nilai $t_{\text {hitung }}$ sebesar $1.729167<\mathrm{t}_{\text {tabel }}$ sebesar 1.9990 yang berarti komisaris independen (komind) tidak berpengaruh terhadap kinerja keuangan (knrkeu). Hasil penelitian ini sejalan dengan penelitian Emilia Susanti (2012), dan Adil Ridlo Fadillah (2015) yang menyatakan bahwa komisaris independen tidak mempunyai pengaruh terhadap kinerja keuangan. Tetapi hasil penelitian ini tidak sejalan dengan hasil penelitian yang dilakukan oleh Eva Elisetiawati da Budi Artinah (2014), dan Wisma Tytus Harimukti (2016) yang menyatakan bahwa komisaris independen berpengaruh positif terhadap kinerja keuangan. Perbedaan hasil penelitian tersebut terjadi karena disetiap perusahaan jumlah anggota dewan komisaris berbeda-beda dan kepentingan setiap anggota dewan komisaris pun berbeda-beda. Komisaris independen mempunyai tujuan untuk memberikan keseimbangan dalam pengembalian keputusan perusahaan, khususnya dalam rangka perlindungan terhadap pemegang saham kecil atau minoritas dan pihak-pihak yang terkait didalam perusahaan tersebut. Dalam hal demikian dapat ditarik kesimpulan bahwa keberadaan komisaris independen dalam suatu perusahaan dapat mempengaruhi timeliness pelaporan keuangan yang dihasilkan oleh manajemen. Jika perusahaan memiliki komisaris independen di dalam perusahaan maka laporan keuangan yang disajikan oleh manajemen cenderung lebih berintegritas, karena didalam perusahaan ter- dapat badan yang mengawasi dan melindungi hak pihak-pihak diluar manajemen perusahaan salah satunya adalah komisaris independen.

Fama dan Jansen (1983) dalam Arief \& Bambang (2007) memberikan pernyataan bahwa non-execuitive direktor (komisaris independen) berfungsi dan dapat bertidak sebagai penengah jika terjadi perselisihan diatara para manajer internal dan mengawasi kebijakan manajemen serta memberikan nasihat kepada manajemen didalam perusahaan. Komisaris independen diwajibkan memiliki peranan yang cukup aktif dalam peninjauan kebijakan dan praktik pelaporan keuangan. Komisaris independen diperlukan para dewan untuk memantau dan mengawasi tindakan dewan komisaris karena perilaku opportunistik mereka (Jansen \& Meckling, 1976) Mance (1986) dalam Arifin (2005) menemukan bahwa pengawasan dewan komisaris terhadap manajemen pada umumnya tidak efektif. Ini terjadi karena proses pemilihan dewan komisaris yang masih kurang independent dan demokratis dimana kandidat dewan komisaris biasanya dipilih oleh manajemen sehingga setelah terpilih tidak berani memberikan kritik terhadap manajemen dalam perusahaan yang dimaksud.

Hasil pengujian hipotesis kedua, Nilai Beta kepemilikan institusional (kepinst) sebesar 0.007281 yang menandakan bahwa kepemilikan institusional (kepinst) mempunyai pengaruh terhadap kinerja keuangan (knrkeu). Nilai signifikan sebesar $0.3332>0.05$ dengan nilai $t_{\text {hitung }}$ sebesar $0.975368<\mathrm{t}_{\text {tabel }}$ sebesar 1.9990 yang berarti kepemilikan institusional (kepinst) tidak berpengaruh terhadap kinerja keuangan (knrkeu). Hasil penelitian ini sejalan dengan penelitian Eva Elisetiawati dan Budi Artinah (2014), Adil Ridlo Fadillah (2015), dan Laurensia Chintia Dewi (2014) yang menyatakan bahwan kepemilikan institusional tidak berpengaruh signifikan terhadap kinerja keuangan. Tetapi hasil penelitian ini tidak sejalan dengan hasil penelitian yang dilakukan oleh Emilia Susanti (2012), dan Wisma Tytus Harimukti (2016) yang menyatakan bahwa kepemilikan institusional mempunyai pengaruh signifikan positif terhadap kinerja keuangan. Institusin dapat dijadikan 
alat monitoring terhadap kebijakan-kebijakan yang dibuat perusahaan karena institusi dianggap lebih mempunyai pengalaman dalam menjalankan operasional perusahaan dari pada para investor pubik lainnya (Handayani, 2007). Kepemilikan institusional yang tinggi memungkinkan dikendalikannya perilaku manajer agar tidak berusaha memaksimalkan dirinya sendiri karena kepemilikan ini mewakili serta sumber kekuasaan yang dapat digunakan untuk mendukung/melarang tindakan/keputusan manajemen, sehingga manajer akan berupaya untuk meningkatkan kinerja perusahaan. Dengan kata lain semakin tingginya kepemilikan institusional akan mengurangi nilai dari agency cost. Kepemilikan institusional, pada dasarnya dapat bertindak sebagai pihak yang memantau kegiatan didalam perusahaan. Semakin besar kepemilikan institusional maka semakin efisien pemanfaatan aktiva perusahaan dan diharapkan juga dapat bertindak sebagai pencegahan terhadap pemborosan yang dilakukan oleh manajemen (Faizal, 2004). Begitu pula menurut Wening (2009) semakin besar kepemilikan oleh institusi keuangan maka semakin besar pula kekuatan suara dan dorongan untuk mengoptimalkan nilai perusahaan. Menurut $\mathrm{Xu}$ abd Wabg, et al. dan Bjuggren et al., (dalam tarjo, 2008) bahwa kepemilikan institusional berpengaruh secara positif terhadap nilai perusahaan dan kinerja perusahaan. Dalam hal ini berarti menunjukkan bahwa kepemilikan institusional menjadi mekanisme yang handal sehingga mampu memberikan motivasi bagi para manajer dalam peningkatan kinerjanya yang pada akhirnya dapat meningkatkan nilai perusahaan.

Hasil pengujian hipotesis ketiga, Nilai Beta dept to equity ratio (DER) sebesar -0.162996 yang menandakan bahwa dept to equity ratio (DER) mempunyai pengaruh terhadap kinerja keuangan (knrkeu). Nilai signifikan sebesar $0.0000>0.05$ dengan nilai $\mathrm{t}_{\text {hitung }}$ sebesar -5.051495 $<\mathrm{t}_{\text {tabel }}$ sebesar 1.9990 yang berarti dept to equity ratio (DER) mempunyai pengaruh terhadap kinerja keuangan (knrkeu). Penelitian ini tidak sejalan dengan penelitian Eva Elisetiawati dan Budi Artinah (2014), Emilia Susanti (2012), dan Wisma Tytus Harimukti (2016) yang menyatakan bahwa dept to equity ratio berpengaruh terhadap kinerja keuangan. Jadwal pembayaran pokok dan atau bunga hutang pada tanggal yang telah ditetapkan tidak akan mencegah manajemen untuk overinvestment dalam menggunakan free cash flow. Pembelian kembali saham yang beredar tidak akan dapat dilakukan apabila perusahaan memperoleh sumber dana yang cukup dari berhutang. Kondisi ini dapat tidak menjadi insentif bagi manajer, walaupun mereka juga memiliki saham perusahaan. Menurut Bringham (2001) penggunaan hutang pada level tertentu dapat menggunakan biaya modal perusahaan karena biaya atas hutang merupakan pengurangan atas pajak perusahaan, serta dapat meningkatkan harga saham, dimana pada akhirnya hal ini akan menguntungkan manajemen, investor, kreditor dan perusahaan. Kebijakan terhadap hutang pada tingkat tertentu merupakan suatu praktek untuk memaksimalkan utility dan nilai pasar terhadap perusahaan, dalam hal ini juga merupakan salah satu dari bagian praktik manajemen laba. Hutang yang terlalu besar juga akan menimbulkan konflik antara pihak keagenan antara pemegang saham (shareholders) dengan kreditur (debtholders) sehingga memunculkan biaya keagenan hutang. Hutang yang terlalu besar meningkatkan keinginan shareholders untuk memilih proyek-proyek yang lebih berisiko dengan harapan akan memperoleh return yang lebih tinggi. Dilihat dari sudut pandang lain apabila proyek berhasil maka return akan meningkat, dan debtholders hanya menerima sebesar tingkat bunga, dan sisanya dinikmati oleh shareholders. Sebaliknya jika proyek tersebut gagal atau tidak berhasil maka mereka dapat megalihkan penggunaan risiko pada pihak kreditur. Disisi lain penggunaan hutang yang semakin besar dalam struktur modal perusahaan akan menyebabkan biaya bunga semakin besar, sehingga keuntungan perlembar saham yang menjadi hak pemegang saham juga semakin besar, karena adanya penghematan pajak penghasilan badan (Sartono, 2001).

Hasil pengujian hipotesis keempat, untuk uji signifikan regresi berganda dapat dilihat dari data dari hasil pengujian signifikan dan uji F. Hasilnya dapat dilihat pada tabel bahwa nilai $\mathrm{F}_{\mathrm{o}}=9.392946$ 
dengan nilai signifikan sebesar $0.000034<0.05$ yang berarti komisaris independen (komind), kepemilikan institusional (kepinst) dan dept to equity ratio (DER) secara bersama-sama mempunyai pengaruh terhadap kinerja keuangan (knrkeu). Berdasarkan hasil dari perhitungan diatas maka $\mathrm{H}_{\mathrm{a}}$ diterima dan $\mathrm{H}_{\mathrm{o}}$ ditolak, berarti komisarisindependen (komind), kepemilikan institusional (kepinst) dan dept to equity ratio (DER) mempunyai pengaruh terhadap kinerja keuangan (knrkeu) secara simultan. Hasil penelitian ini sejalan dengan penelitian Eva Elisetiawati dan Budi Artinah (2014), Emilia Susanti (2012), Adil Ridlo Fadillah (2015), dan Wisman Tyus Harimukti (2016).

\section{SIMPULAN}

Nilai Beta komisaris independen (komind) sebesar 0.615116 yang menandakan bahwa komisaris independen (komind) mempunyai pengaruh terhadap kinerja keuangan (knrkeu). Nilai signifikan sebesar $0.0888>0.05$ dengan nilai $\mathrm{t}_{\text {hitung }}$ sebesar $1.729167<\mathrm{t}_{\text {tabel }}$ sebesar 1.9990 yang berarti komisaris independen (komind) tidak berpengaruh terhadap kinerja keuangan (knrkeu).

Nilai Beta kepemilikan institusional (kepinst) sebesar 0.007281 yang menandakan bahwa kepemilikan institusional (kepinst) mempunyai pengaruh terhadap kinerja keuangan (knrkeu). Nilai signifikan sebesar $0.3332>0.05$ dengan nilai $\mathrm{t}_{\text {hitung }}$ sebesar $0.975368<\mathrm{t}_{\text {tabel }}$ sebesar 1.9990 yang berarti kepemilikan institusional (kepinst) tidak berpengaruh terhadap kinerja keuangan (knrkeu).

Nilai Beta dept to equity ratio (DER) sebesar -0.162996 yang menandakan bahwa dept to equity ratio (DER) mempunyai pengaruh terhadap kinerja keuangan (knrkeu). Nilai signifikan sebesar $0.0000>0.05$ dengan nilai $\mathrm{t}_{\text {hitung }}$ sebesar -5.051495 $<\mathrm{t}_{\text {tabel }}$ sebesar 1.9990 yang berarti dept to equity ratio (DER) mempunyai pengaruh terhadap kinerja keuangan (knrkeu).

Untuk uji signifikan regresi berganda dapat dilihat dari data dari hasil pengujian signifikan dan uji F. Hasilnya dapat dilihat pada tabel bah- wa nilai $F_{o}=9.392946$ dengan nilai signifikan sebesar $0.000034<0.05$ yang berarti komisaris independen (komind), kepemilikan institusional (kepinst) dan dept to equity ratio (DER) secara bersama-sama mempunyai pengaruh terhadap kinerja keuangan (knrkeu). Berdasarkan hasil diatas maka $\mathrm{H}_{\mathrm{a}}$ diterima dan $\mathrm{H}_{\mathrm{o}}$ ditolak, berarti komisaris independen (komind), kepemilikan institusional (kepinst) dan dept to equity ratio (DER) mempunyai pengaruh terhadap kinerja keuangan (knrkeu) secara simultan.

\section{PENGHARGAAN}

Penulis menyadari keberhasilan dalam menyelesaikan penelitian ini tidak terlepas dari bimbingan, arahan, do'a dan dukungan dari berbagai pihak yang dengan ketulusan, dan pengorbanan memberikan bantuanya sampai dengan selesainya penelitian ini. Oleh karena itu, pada kesempatan ini penulis ingin menyampaikan rasa terimakasih yang sebesar-besarnya kepada:

1. Ibu Dr. Reschiwati, S.E., MM., Ak., CA dan Bpk. Dr. Wawan Subawan, Ak., MM selaku pembimbing penelitian yang telah banyak memberikan dukungan, masukan dan koreksi dalam proses penyelesaian ini.

2. Bapak Dr. J. Sumarno, SE., MM., Ak selaku pembina penelitian.

3. Bapak Drs. H. Darsono selaku Ketua Yayasan Sasmita Jaya, Bapak Dr. H. Dayat Hidayat, M.M. selaku Rektor Universitas Pamulang, Bapak Dr. H. Endang Ruhiyat, S.E., M.M., CSRA., CMA. selaku Dekan Fakultas Ekonomi Universitas Pamulang dan Ibu Effriyanti, S.E., Akt., M.Si., CA. selaku Kepala Program Studi Akuntansi S1 yang telah memberikan kesempatan sehingga penulis dapat menyelesaikan penelitian ini.

4. Untuk kedua orang tua penulis (Alm. Bpk. M. Solihin dan Ibu C. Monirah) yang penulis kasihi dan sayangi sepenuh hati, serta kakakkakak (Cie'Tinny, Cie'Khinta, Cie'Mei, Cie'Nitta, Alm. Ko'Joko dan Cie'Laura) yang selalu mendoakan dan mendukung baik secara moral maupun materil selama proses penyelesaian penelitian ini. 
5. Untuk seseorang yang teristimewa dalam hidup penulis (Sdr. Damar Kurniawan), yang selalu menemani dan memberikan semangat yang tiada henti hingga selesainya penelitian ini.

6. Semua kerabat, sahabat, serta pihak yang secara langsung maupun tidak langsung memberikan dukungan dan semangat dalam penyusunan dan penyelesaian penelitian ini.

Semoga Tuhan Yang Maha Esa membalas budi baik dan selalu diberi keberkahan hidup, dan selalu dalam lindungan-Nya. Atas segala hal yang telah dilakukan penulis dalam penyelesaian penelitian ini, tentunya terdapat kesalahan baik yang disengaja maupun yang tidak disengaja. Penulis meminta maaf kepada pihak-pihak yang merasa dirugikan.

Akhirnya semoga penelitian ini dapat bermanfaat dan menambah pengetahuan bagi seluruh khasanah pembaca dan masyarakat lainnya. Amin.

\section{DAFTAR PUSTAKA}

Adi, W. S. (2008). Pengaruh Mekanisme Corporate Governance Terhadap Agency Cost pada perusahaan manufaktur yang terdaftar di Bursa Efek Indonesia. Skripsi S1 FE-UMS, Tidak Dipublikasi.

Arief, dkk. (2015). Pengaruh Good Corporate Governance dan Financial Leverage terhadap Kinerja Keuangan dan Nilai Perusahaan. Jurnal Riset Akuntansi Indonesia. Diakses dari http://docplayer.info/165198422Bab-v-penutup-corporate-governanceukuran-perusahaan-dan-financial-leverageterhadap.html.

Arifin, Z. (2005). Hubungan antara Corporate Governance dan Variabel Pengurang Masalah Agensi. Jurnal Siasat Bisnis, Vol. 1 No. 10. Juli, hal. 39-55. Diakses dari https://journal. uii.ac.id/.

Bambang, R. (2001). Dasar-Dasar Pembelanjaan Perusahaan, Edisi Keempat, Cetakan Ketujuh. Yogyakarta: BPFE.

Bodroastuti, T. (2009). Pengaruh Struktur Corporate Governance Terhadap Financial
Distress, working paper STIE Widya Manggala Semarang.

Brigham, E. F dan Houston. (2008). Manajemen Keuangan Edisi Delapan, buku 1. Jakarta: Salemba Empat.

Chen, S., \& Zhang. (2006). After Enron Auditor Conservatism and Ex- Anderse Clients. The Accounting Review, 49-82. Diakses dari https://aaapubs.org/doi/pdf/.

Dermawati, D. et al. (2004). Hubungan Corporate Governance dan Kinerja Perusahaan, Simposium Nasional Akuntansi VII, Denpasar. Diakses dari http://scholar.google.co.id/.

Dewi, D. S., Susbiyani, A., \& Syahfrudin, A. (2019). Pengaruh Penerapan Good Corporate Governance, Total Asset Turn Over dan Kepemilikan Institusional Terhadap Kinerja Keuangan Perusahaan. International Journal of Social Science and Business, Vol 3 No 4. Diakses dari https://jurnal.univpgripalembang.ac.id/index.php/neraca/article/ view/3843.

Dewi, L.C. (2014). Pengaruh Struktur Kepemilikan dan Dewan Komisaris Independen Terhadap Nilai Perusahaan. Jurnal Universitas Kristen Satya Wacana. Diakses dari https:/ojs.uajy. ac.id/index.php/kinerja/article/view/518.

Elisetiawati, E, dkk. (2014). Pengaruh Pelaksanaan Good Corporate Governance, Kepemilikan Institusional dan Leverage terhadap Kinerja Keuangan. Jurnal Riset Akuntasi Indonesia. Diakses dari http://journals.ums.ac.id/index. $\mathrm{php} /$ benefit/article/download/.

Fadillah, R. A. (2015). Analisis Pengaruh Dewan Komisaris Independen, Kepemilikan Manajerial dan Kepemilikan Institusional Terhadap Kinerja Keuangan. Jurnal. Universitas Siliwangi. Diakses dari http://jurnal.unsil.ac.id/ index.php/jak/article/view/294.

Faizal. (2004). Analisis Agency Costs, Struktur Kepemilikan dan Mekanisme Corporate Governance. Simposiun Nasional Akuntansi VII. Diakses dari http://jurnal.unsyiah.ac.id/ JAROE/article/view.

Ghozali, I. (2013). Analisis Multivariat dan Ekonometrika (Teori, Konsep, dan Aplikasi dengan Eviews 8), Semarang: Universitas Dipo- 
negoro.

Iskarisma, E. (2017). Pengaruh Current Ratio, Total Asset Turnover, Inventory Turnover, Debt To Equity Ratio dan Umur Perusahaan Terhadap Return On Asset pada Perusahaan Food and Beverage Yang Terdaftar Di Bei Tahun 2011-2015.

Isnanta, R. (2008). Pengaruh Corporate Governance dan Struktur Kepemilikan terhadap Manajemen Laba dan Kinerja Keuangan. Yogyakarta: Fakultas Ekonomi Universitas Islam Indonesia.

Kasmir. (2016). Bank dan Lembaga Keuangan Lainnya. Edisi Revisi 2008. Jakarta: PT. Rajagrafindo Persada.

Komite Nasional Kebijakan Governance (KNKG). (2006). Pedoman Umum Good Corporate Governance Indonesia. Jakarta.

Noor, H. F. (2009). Investasi Pengelolaan Keuangan dan Pengembangan Ekonomi Mayarakat. Jakarta: PT. Indeks.

Oktodella, D. (2011). Analisis Corporate Governance Terhadap Integritas laporan Keuangan. Universitas Diponegoro Semarang. Diakses dari http://eprints.undip.ac.id/28639/1/ JURNAL.pdf.

Pranata, Y. (2007). Pengaruh Penerapan Corporate Governance Terhadap Kinerja Keuangan Perusahaan. Universitas Islam Indonesia, Yogyakarta. Diakses dari http://eprints.undip. ac.id/.

Ramdiani Nyoman, N,dkk. (2012). Pengaruh Good Corporate Governance dan Kinerja Keuangan pada Harga Saham Perbankan. Jurnal Riset Akuntansi Indonesia. Diakses dari https://docplayer.info/39618459-Corporategovernance-dan-kinerja-keuangan-studikasus-pada-perusahaan-perbankan-yangterdaftar-di-bei-periode.html.

Sartono, A. (2010). Manajemen Keuangan Teori dan Aplikasi. Yogyakarta: BPFE.

Subagia, A. (2009). Telaah terhadap Mekanisme Corporate Governance dan Manajemen Laba serta Pengaruhnya terhadap Kinerja Keuangan. Yogyakarta: Universitas Muhammadiyah Yogyakarta. Diakses dari http://ejournal. unp.ac.id/students/index.php/akt/article/ view/657.

Sucipto. (2013). Pengaruh Kinerja Keuangan. Jurnal Akuntansi. Universtas Sumatera Utara. Medan. Diakses dari https://jurnal.stie-aas. ac.id/index.php/jap/article/view/1078.

Sugiyono. (2004). Metode Penelitian Bisnis. Bandung: Alfabeta.

Suranti, E. (2011). Pengaruh Pelaksanaan Good Corporate Governance, Kepemilikan Institusional dan Leverage terhadap Kinerja Keuangan. Diakses dari http://ejournal.unp.ac.id/.

Suratman, A. (2010). Good Corporate Governance: Konsep dan Permasalahannya. Jakarta: PT. Trintamas.

Susanti, E. (2012). Pengaruh Pelaksanaan Good Corporate Governance, Kepemilikan Institusional dan Leverage terhadap Kinerja Keuangan. Jurnal Riset Akuntansi Indonesia. Diakses dari http://journals.ums.ac.id/index. php/benefit/article/view/2309.

Tarjo. (2008). Pengaruh Konsentrasi Kepemilikan Institusional dan Leverage Terhadap Manajemen Laba, Nilai Pemegang saham serta Cost of Equity Capital. Simposium Nasional Akuntansi XI. Pontianak. Diakses dari http:// pdeb.fe.ui.ac.id/?p=6535.

Tjeger, I N.. (2003). Corporate Governance: Tantangan dan Kesempatan Bagi Komunitas Bisnis Indonesia. Jakarta. Prenhalindo.

Tunggal, H. S. (2013). Internal Audit dan Corporate Governance. Jakarta: Harverindo.

Ujiyantho, A. M. dan B.A. Pramuka. (2007). Mekanisme Corporate Governance, Manajemen Laba dan Kinerja Keuangan. Simposium Nasional Akuntansi X, Makassar. Diakses dari http://pdeb.fe.ui.ac.id/?p=7112.

Wardhani, R. (2006). Mekanisme Corporate Governance dalam Perusahaan yang Mengalami Permasalahan Keuangan (Financilly Distressed Firms).

Wening, K. (2009). Pengaruh Kepemilikan Institusional Terhadap Kinerja Keuangan Perusahaan. 